УДК 351.755.61-027.63(477)"1917/1921"

DOI 10.31654/2520-6966-2019-11i-94-48-60

\title{
К. Петриченко
}

молодший науковий співробітник

Національної бібліотеки України імені В. І. Вернадського (м. Київ, Україна)

\section{Український закордонний паспорт періоду Української революції (1917-1924 рр.): за матеріалами відділу зарубіжної україніки Інституту книгознавства Національної бібліотеки України імені В. І. Вернадського}

Стаття присвячена огляду літератури фронду відділу зарубіжної україніки Інституту книгознавства Національної бібліотеки України імені В. І. Вернадського з питань вивчення українського закордонного паспорта впродовж усього періоду його існування та використання: від моменту висловлення пропозиції про його запровадження - 28 листопада 1917 р. $i$ до часу існування дипломатичних місій, що видавали українські закордонні паспорти, - у 1924 p.

Основну увагу у ній зосереджено на мемуарах сучасників подій: дипломатів, державних діячів, творчої інтелігенції. Аналіз мемуарної літератури дає підстави стверджувати, що вона має важливе наукове значення, оскільки містить документальні свідчення про використання українських закордонних паспортів для виїду украӥнських громадян, зокрема євреїв, до різних країн Європи та Америки; висвітлює існування як дипломатичного, так $i$ звичайного українського паспортів різних державних утворень періоду Української революції- Української Держави, очолювана гетьманом Павлом Скоропадським, Української Народної Республіки, Західноукраїнської Народної Республіки.

Крім того, у статті розглянуто великий масив інформації про український закордонний паспорт в літературі української діаспори 1920-2000-х рр. У ній велику увагу зосереджено на висвітленні діяльності українських дипломатичних місій та консульств, їх періоду існування та специфріки роботи, подано зразки українських закордонних паспортів та описано їх вигляд і значення в історії розвитку української державності.

Ключові слова: відділ зарубіжної україніки Інституту книгознавства Національної бібліотеки України імені В. І. Вернадського, мемуари, український закордонний паспорт, дипломатія, фонд. 
Українська революція 1917 р. спричинила піднесення національної свідомості, одним із проявів якої стало бажання вирізнятися від сусідів і в документах. Тому саме у період Української Центральної Ради постала потреба запровадження саме українського закордонного паспорта.

У фоонді відділу зарубіжної україніки Інституту книгознавства Національної бібліотеки імені В. І. Вернадського (ВЗУ ІК НБУВ - К. П.) зосереджено цілий пласт літератури, присвяченої Українській революції та, зокрема, зовнішній політиці національних урядів - Української Центральної Ради, Гетьманату, Західноукраїнської Народної Республіки та Директорії, одними із важливих документів якої виступають дипломатичні та звичайні закордонні паспорти українських громадян.

Метою даної статті є огляд літератури фонду відділу зарубіжної україніки Інституту книгознавства Національної бібліотеки України імені В. І. Вернадського, присвяченої українському закордонному паспорту періоду 1917-1924рр., зокрема у спогадах сучасників і працях дослідників української діаспори.

Автором визначено такі завдання:

1) подати класифікацію літератури, в якій зосереджена дана інформація;

2) розглянути спогади діячів періоду Української революції, що стосуються питань вивчення українського закордонного паспорта;

3) дослідити праці та статті дослідників української діаспори, які містять інформацію з окресленого питання.

Вивченням української дипломатії в часи Української революції, а зокрема і розглядом питання українського закордонного паспорта займалися як сучасники подій Української революції - Д. Дорошенко [7], Є. Онацький [12], П. Карманський [10], М. Рудницький [14], В. Прокопович [13] тощо, так і дослідники XX ст., що проживали в зарубіжжі, - Б. Галайчук [5], Л. Васильківський [1], В. Трембіцький [18; 19; 20; 21] та інші.

Як відомо, вперше потребу у національних закордонних паспортах висловив генеральний секретар Олександр Шульгін - 28 листопада 1917 р. на засіданні Генерального Секретаріату під час обговорення інформації та пропозиції у справах закордонних і замирення було визнано "принципіально бажаним видачу громадянам Української Республіки, що бажають виїхати за кордон, закордонних паспортів від Української Республіки" [16, с. 481].

Найбільше інформації про пам'ятки дипломатії у фондах ВЗУ ІК НБУВ міститься у спогадах очевидців того часу - дипломатів, урядовців, представників творчої інтелігенції тощо. 
Одним із перших спогадів, віднайдених у фондах ВЗУ ІК НБУВ, про закордонний паспорт періоду Української Держави Гетьмана Павла Скоропадського є матеріал Осипа Залеського, відомого галицького педагога, композитора, диригента, якого розпад АвстроУгорщини застав у Могилеві-Подільському.

В оповіді йдеться про те, щоб доїхати до Могилева в Україні, наприклад, із Варшави, потрібно було мати "заграничний пашпорт", який можна було дістати в українській міліції [8, с. 78].

Також автор повідомив, що видавалися перепустки для проїзду залізницею з Могилева до Чернівців (з метою лікування), якщо необхідного спеціаліста на території України не було (для цього потрібне було підтвердження - посвідка від місцевого лікаря [8, с. 77]. Перепустки видавались лише для місцевих мешканців і були дійсні лише 1 добу [8, с. 78].

Зі спогадів Євгена Онацького "По похилій площині. Записки журналіста і дипломата" дізнаємося, що українські посольства видавали закордонні паспорти і вказували у них фах особи. Наприклад, йому у Відні було виставлено новий паспорт із фахом агронома [12, с. 6].

Як відомо з біографії автора, увійшовши у жовтні 1919 р. до складу Української дипломатичної місії в Італії, він був там спершу директором пресового бюро, пізніше - секретарем та завідувачем справами місії до закінчення ії̈ діяльності у 1922 р. [4, с. 175].

322 квітня 1919 р. до Царгорода прибув новий український посол профресор О. Лотоцький, який очолив українське посольство у Туреччині [11, с. 91].

Як зазначено у статті 3. Веснянського, що була підготовлена на основі спогадів О. Лотоцького, спочатку посольство мало характер консульський, тобто "видавали пашпорти та ставили візи для втікачів із Одеси, українським громадянам, яких нараховувалося тоді у Царгороді біля 40.000 осіб" [3, с. 21-22].

Блок спогадів, що стосуються розвитку української дипломатії, а зокрема, і згадок про український закордонний паспорт, міститься в історичному календарі-альманасі "Червоної калини" на 1939 р.

Зокрема, Михайло Рудницький, український літературний критик, літературознавець, письменник, поет, перекладач, з березня 1919 р. був секретарем дипломатичної місії УНР у Парижі. Автор описує події напередодні Паризької конференції 1919 р. - про приїзд української делегації. Як писав автор, який також був у її складі, власники готелів і комісаріати поодиноких дільниць, дістаючи паспорти наших земляків, уперше чули про національність "українську" і не раз не могли це погодити зі своїми звичками і своїм знанням географії [14, с. 121]. 
На початку 1919 р. постановою Директорії УНР до Угорщини було вислано Надзвичайну Дипломатичну Місію, головою якої було призначено Миколу Галагана. 26 січня 1919 р. Місія прибула до Будапешта. За спогадами Івана Стасіва, одного з її членів та перекладача, Місія захищала інтереси своїх громадян [17, с. 667]. Незважаючи на зміни урядів Угорщини, ставлення їх до української Місії було коректне, навіть із зрозумінням і симпатією до боротьби українського народу за державну незалежність $[17$, с. 668].

У зв'язку із переслідуванням євреїв до Місії активно зверталися українські громадяни єврейської національності з метою одержання паспорта і права проживання в Угорщині. За допомогою своїх організацій вони (з українськими паспортами) діставали візи на виїзд до різних країн Західної Європи, а також до Америки [17, с. 668].

У той час коли українські землі мали спільний кордон з Угорщиною, через Будапешт проїздили різні наші місії, комісії, політичні особистості. Для них Місія УНР виготовляла різні візи в"їзду чи переїзду до тих держав, до яких вони мали призначення. Часто були труднощі із візами на виїзд чи на переїзд, бо не всі консули та їх уряди визнавали Українську державу, а отже, і українські паспорти. Але, як пише І. Стасів, "наше представництво в Угорщині було трактоване на рівні з іншими дипломатичними представництвами і ми завжди мали успіх" [17, с. 669].

Відомо також, що у 1924 р. Будапешт відвідав головний отаман Симон Петлюра разом із В. Прокоповичем. Тут він не затримався довго і виїхав через Швайцарію до Парижа [17, с. 671].

Про цю подорож В. Прокопович лишив спогади, що були надруковані в "Збірнику пам'яті С. В. Петлюри". У розвідці очевидця подій йдеться про виїзд автора разом з С. Петлюрою з Польщі до Австрії у грудні 1923 р. Цікаво, що Петлюра виїздив під іменем і прізвищем Степана Могили, начальника пресової служби дипломатичної місії в Будапешті. А В. Прокоповича "каприз паспорта повернув чомусь у нашого торговельного агента в Угорщині" [13, с. 213].

Як згадував у своєму біографічному нарисі, присвяченому В'ячеславу Прокоповичу, Андрій Яковлів, "під прибраними прізвищами, з пашпортами урядовців нашої дипломатичної місії в Угорщині, виїхали вони вночі 31 грудня 1923 р. з Варшави в напрямі на Відень і Будапешт. Перебувши деякий час в Будапешті, поїхали вони до Швейцарії, де була ще наша місія. Прожили досить довго в Женеві, а на початку осени 1924 р. приїхали в Париж" [23, с. 9].

Глибше дає зрозуміти роботу посольств УНР за кордоном звіт доктора медицини Євмена Лукасевича про діяльність українського 
посольства у Швейцарії, який було поміщено у статті Л. Васильківського як ії окремий розділ [2, с. 75-92].

3 нього дізнаємося про прихильне ставлення до українців від політичного департаменту швейцарського уряду: "пашпорти, які ми виставляли нашим громадянам, визнавалися швейцарським урядом [2, с. 88].

Цікавим фрактом, що наводиться у звіті, $€$ те, що посольство УНР після виїзду більшовицької місії з Швейцарії було фактично єдиним представником з території колишньої Росії. Тому до нього масово звертались російські громадяни, народжені на території України, бажаючи виміняти більшовицькі паспорти на українські, щоб не підлягати висилці зі Швейцарії [2, с. 88].

У спогаді зазначено, що усі члени посольства УНР одержали від політичного департаменту Швейцарської конфедерації дипломатичні легітимації [2, с. 87].

У щоденнику української громадської діячки та педагога Софії Русової нотатки про паспорт є епізодичними. Спершу, за 10 червня 1920 р., автор згадувала про існування у неї (як урядовця УНР) дипломатичного паспорта, за допомогою якого вона прагнула поїхати до сина Юрія, який працював у Відні [15, с. 259]. У мемуарах С. Русова розповідає про нелегальний перехід р. Збруч. I лише тільки під час перебування у Тарнові їй вдалося дістати паспорт з Кракова до Відня [15, с. 226].

У фрондах ВЗУ ІК НБУВ містяться також спогади діячів Української революції 1917-1924 рр., що стосувалися дипломатичної роботи та існування закордонного паспорта на землях Західноукраїнської Народної Республіки (ЗУНР), що відрізнявся від закордонних паспортів УНР лише атрибутикою.

3 мемуарів відомого українського дипломата та історика Дмитра Дорошенка "Мої спомини про недавнє минуле" ми дізнаємось про існування іншого паспорта, що видавався для громадян ЗУНР для виїзду за кордон. Автор згадував про свій намір поїхати зі Станіславова до Праги для придбання друкарських машин і приладдя. У зв'язку з цим, на прохання М. Лозинського, секретаря закордонних справ, Д. Дорошенко отримав "галицький" закордонний паспорт [7, с. 38].

Також зі спогадів Д. Дорошенка довідуємось, що галичани, на відміну від представників Директорії УНР, мали свої окремі інституції та посольство у Відні. Здебільшого "пражане" перекочовували до Відня, а були такі, що "сновигали туди й сюди між Прагою та Віднем. Цікавим є фракт, що їхні українські дипломатичні паспорти (десь приблизно 9 з 10 усіх приїзжих земляків мали дипломатичні паспорти) у той час визнавались" [7, с. 49]. За даними автора, це була друга половина травня 1919 р. 
Відомий поет, перекладач, громадський діяч П. Карманський у своїх спогадах продовжував розповідь про дипломатичну роботу ЗУНР - наприкінці лютого 1922 р. він вирушив до Бразилії, за дорученням уряду ЗУНР у вигнанні для збору коштів на оборону серед українських емігрантів у Бразилії. Потрібно відзначити ту деталь, що він не мав формального призначення на дипломатичного представника, але в його дипломатичному паспорті було зазначено, що він був представником уряду ЗУНР [10, с. 3].

Аналіз мемуарної літератури про дипломатичну роботу та український закордонний паспорт дає підстави стверджувати, що вона має важливе наукове значення, оскільки містить як документальні свідчення, так і аналіз роботи дипломатичних представництв, висвітлює значення вказаного документа для життя та діяльності громадян в часи Української революції.

Великий об'єм інформації про український закордонний паспорт зосереджено у статтях різних журналів і часописів, а також літературі, що виходила за кордоном.

Однією з перших згадок про нього є публікація у суспільно-політичному тижневику "Воля", що друкувався у Відні у 1919-1921 рр. У ній йдеться про діяльність української військово-санітарної місії у Відні, в якій керівником 15 грудня 1918 р. був затверджений Андрій Окопенко. У той час у зв'язку із польськими впливами у військовому міністерстві у Відні було стримано видачу паспортів Місії більше як на місяць [6, с. 166].

Наступною слід відмітити працю "Українець у Франції". Це українсько-фрранцузький порадник, що вийшов у 1934 р. Щодо питання паспорту відзначено, що кожен, хто бажає в"їхати до Франції, мусить мати свій національний паспорт. Про заробітчан із Західної України йдеться, що вони одержують польський паспорт, що його видає адміністративна влада Міністерства внунтрішніх справ на місці, а емігранти з Наддніпрянщини одержують від тієї країни, з якої їдуть, до Франції так званий нансенівський паспорт. Діти до 15 років мусять бути дописані до паспорта одного з батьків [22, с. 49].

Значний інтерес становить одна із статей українського діаспорного часопису 40-х рр., що містить інфформацію про три українські місії у Вашигтоні [9], одним із завдань яких було видавати українські закордонні паспорти.

Першою була придніпрянська, а дві останні - галицькі [9, с. 291]. 2 серпня 1919 р. до Нью-Йорка з Данії приїхала місія уряду Симона Петлюри, до складу якої входили: Юліан Бачинський (голова), Віктор Козакевич - секретар, доктор Мусій Кадець - заступник секретаря [9, c. 291]. 
Друга місія - західноукраїнська - у Вашингтоні була організована доктором Лонгином Цегельським, щоб вирішити справи Східної Галичини, яку з 25 червня 1919 р. було передано Польщі [9, с. 291].

1 липня 1921 р. доктор Цегельський проголосив відкриття Дипломатичного Представництва ЗУНР у Вашингтоні в будинку, де була попередня місія УНР з Ю. Бачинським. Ліквідацію місії було розпочато з часу проголошення рішення Ради Амбасадорів у Справі Галичини (від 15 березня 1923 р.). Хоча паспорти видавались ще до кінця 1923 р. [9, с. 293].

Оскільки видача як дипломатичного, так і звичайного закордонних паспортів за кордоном була пов'язана із дипломатичними представництвами або консульствами УНР або ЗУНР в інших країнах, то важливим є розглянути і питання, пов'язані з їх періодом існування та специфікою діяльності.

Однією із загальних праць, що містяться у фонді ВЗУ ІК НБУВ, дані питання представлено в Енциклопедії українознавства у статті під назвою "Дипломатія" [5]. У розбудові мережі дипломатичних представництв відродженої Української держави з 1918 р. Б. Галайчук виокремив кілька етапів. Першим є етап за існування Української Центральної Ради, коли у грудні 1917 р. уряд приймав представників Англії, Франції та Румунії [5, с. 512]. Згідно з Берестейським миром, УНР "нав'язувала дипломатичні взаємини з центральними державами, обмінявшись послами з Німеччиною, Австро-Угорщиною і Туреччиною та вислала представника до Румунії".

Наступним етапом є період існування Гетьманської держави, коли українські дипломатичні представники відправлялись до 10 зарубіжних держав і приймали 11 чужих у Києві [5, с. 512]. У період існування Директорії Україна вже мала 11 посольств. Основна діяльність українських дипломатичних представництв і спеціальних делегацій УНР полягала в заходах досяпи визнання України та отримати допомогу в її боротьбі проти Росії та Польщі; вони проводили широку інфрормативну роботу і видавничу роботу про Україну, а також виконували головні консульські фрункції [5, с. 513].

У країнах, де перебували українські полонені, було зорганізовано їх повернення на батьківщину; при представництвах у Берліні, Відні й Римі існували військово-санітарні місії для справ військовополонених [5, с. 513].

ЗУНР зберігала окремі зовнішні взаємини, навіть після приєднання до УНР. Дипломатичні представництва західноукраїнського уряду існували в Австрії (визнане як посольство), Німеччині, Угорщині, Чехо-Словаччині, Італії, Югославії. Спеціальні місії були вислані до країн, в яких перебувала значна кількість еміграції з Галичини - 
Канади, США, Бразилії, хоча вони не мали визнання статусу дипломатичних представництв [5, с. 513].

Після втрати незалежності припинилися стосунки з українськими дипломатичними представниками, визнаючи уряд Української Соціалістичної Радянської Республіки (УСРР) та передаючи йому будинки українських посольств та інше державне майно. В інших державах українські місії припинили свою діяльність через брак фрінансів для утримання дипломатичного апарату екзильного уряду УНР [5, с. 513].

У статті подається також список голів українських місій у період 1918-1923 рp. [5, с. 514].

У праці Л. Васильківського "Причинки до історії української дипломатії в 1917-21 роках" подається інформація, що діяльність дипломатичних представництв Української Народної Республіки тривала від 1918 до 1924 року, у якому більшість представництв було ліквідовано [1, с. 142], у той час як 15 березня 1923 р. перестали існувати усі місії та закордонні представництва ЗУНР [1, с. 141].

Проте одним із найбільших діаспорних дослідників проблемних питань дипломатичного корпусу УНР 1917-1924рр., дослідження якого містяться у фонді ВЗУ ІК НБУВ, $є$ Володимир Трембіцький.

У одній із своїх праць він зазначив, що, вивчаючи період 19181920-х рр., не можна оминути становища України за кордоном - розміщення по столицях 38-ми держав українських посольств чи дипломатичних представництв (місій) та консульських станиць (чотирьох категорій): генеральних, звичайних, віцеконсульств і консульських агентів у винятковому положенні [21, с. 70].

Дослідник подав поділ часу існування дипломатичного корпусу України на три основні періоди: 1) першої республіки, відомої із такою парламентарною установою, як Українська Центральна Рада (до 29 квітня 1918 р.), 2) за гетьманського устрою (від 3-го травня до 14-го грудня 1918 р.) та 3) за Директорії: її прибуття до Києва 19 грудня 1919 року і аж до її виїзду з останнього міста УНР Волочиськ - Закупне та Сатанів - на так звану "польську сторону" у галицькі Підволочиськ чи Гусятин, а звідсіль - особливим поїздом у бік Варшави та згодом на більш постійний побут у м. Тарнів (у південній Польщі) [21, с. 72].

Автор зазначав, що за час тимчасового екзильного періоду (з кінця листопада 1920 р. до кінця червня 1924 року) остаточно закривались останні дипломатичні станції (місії) та консульства УНР і були витіснені радянськими дипломатами [21, с. 71-72].

Отже, як стверджував В. Трембіцький, держава УНР існувала територіально від 20 листопада 1917 р. до 21 листопада 1920 р. А так званий екзильний уряд УНР у Тарнові у Польщі існував повні три роки (1921-1923) та п'ять тижнів 1920 р. (від 21 листопада до 31 грудня) [20, 
с. 253]. Лише в деяких країнах, як-от у Італії та Швейцарії, існувало консулярно-дипломатичне представництво УНР до середини 1924 р.

У журналі "Вісник" (Вісник. Лютий 1968, рік XXII Ч. 2 (227). С. 21-22), що виходив у Нью-Йорку, В. Трембіцький порушив питання, що одним із найважливіших завдань Української держави на міжнародній ниві було встановлення консульських зносин із іншими державами світу [19, с. 21]. Консульськими справами керували Консульський департамент при Міністерстві закордонних справ та Консульська комісія, що опрацьовувала консульський статут, закони та розпорядження і затверджувала форми всіх урядових бланків, посвідчень, звичайних та дипломатичних паспортів (спершу двома, а пізніше чотирма мовами) $[19$, c. 21].

У статті подано багато ілюстрацій та фото. Серед них міститься кілька зразків українських закордонних паспортів, що допомагає читачу побачити їх зовнішній вигляд та наповнення. Усі зразки об'єднує українська символіка - зображення тризуба як герба як на самому паспорті, так і на відбитку печатки.

Наприклад, паспорт УНР, що належав Саві Павлюк. Він був виданий за номером 112620 грудня 1920 р. у Вашингтоні Надзвичайною дипломатичною місією Української Народної Республіки в США. Дійсний був лише один рік. Серед його особливостей: він містив написи двома мовами - українською та англійською. Порівняно з іншими зразками закордонних паспортів у його описі особи вказані зріст, вага, вік, колір очей та волосся власника [20, с. 263].

Наступним документом, що міститься у статті, є зразок паспорта УНР 4 мовами: українською, фрранцузькою, англійською та німецькою. Він був виданий Українською дипломатичною місією у Гаазі (Нідерланди) 13 жовтня 1920 р. і належав українському громадянину Володимирові Тимошенку, директору фрілії у Франції "Дніпро-Союзу" союзу споживчих кооперативних союзів в Україні, народженому 12 квітня 1885 р. в селі Базиліка Конотопського повіту на Чернігівщині. Документ містив 24 сторінки [20, с. 277].

Також у статті подано інший різновид закордонного паспорта УНР, що мав номер 610 та мав 16 сторінок. Він належав Василю Одинському та містив записи 3 мовами: українською, французькою та німецькою [20, с. 279]. Крім того, у статті містилось фото наліпкової печатки з блакитно-жовтими шнурочками, що зв'язували міжнародний паспорт УНР, виданий Дипломатичним Представництвом у Голландії [20, с. 293].

Український діаспорний дослідник В. Трембіцький надавав дипломатичним та звичайним паспортам українських громадян великого значення, бо відзначав їх серед документів, що свідчили про 
державне самовизначення українського народу та про існування української державності як міжнародного чинника, "головною ідеєю якого був мир та рівновага сил в міжнародному укладі у Східній Європі, в Чорноморському обширі та на Далекому Сході" [18, с. 68].

Отже, у статті здійснено огляд літератури фонду ВЗУ ІК НБУВ з питань вивчення українського закордонного паспорта впродовж усього періоду його існування та використання: від моменту висловлення пропозиції про його запровадження - 28 листопада 1917 р. і до часу існування дипломатичних місій, що видавали українські закордонні паспорти - у 1924 р.

Основну увагу у ній зосереджено на мемуарах сучасників подій: дипломатів, державних діячів, творчої інтелігенції. Крім того, розглянуто значну кількість літератури 1920-2000-х рр., у якій розкриваються як окремі сторінки дипломатичної роботи, так і безпосередньо питання, що стосуються українського закордонного паспорту впродовж періоду Української революції.

\section{Література}

1. Васильківський Л. Причинки до історії дипломатії в 1917-21 роках (II). Сучасність. Мюнхен, 1970. Ч. 7-8 (115-116).С. 140-152.

2. Васильківський Л. Причинки до історії української дипломатії в 191721 роках. (Діяльність Українського посольства у Швайцарії в насвітленні д-ра медицини Євмена Лукашевича). Сучасність. Мюнхен, 1970. Ч. 11 (119). С. 75-92.

3. Веснянський 3. Розгром українського посольства (за матеріалами 3 "Сторінки минулого" Проф. О. Лотоцького, ч. 4, 1939). Тризуб. Париж, 1968. 4. 49. С. 19-24.

4. Винар Л. Євген Онацький - чесність з нацією. Український історик. Нью-Йорк; Торонто; Мюнхен, 1980. № 1-4 (65-68). С. 153-179.

5. Галайчук Б. Дипломатія. Енциклопедія українознавства. Словникова частина / Гол. Ред. В. Кубійович. Париж-Нью-Йорк: Молоде Житя, 1955-1957. Т. 2. 800 , с. С. $511-514$.

6. Діяльність Української військово-санітарної місії у Відні. Воля. Відень, 1920. Т. 1. Число 4. С. 166-171.

7. Дорошенко Д. Мої спомини про недавнє-минуле Частина четверта. Під Директорією. На чужині (1919-1920). Львів: Червона калина, 1924. 104 с.

8. Залеський О. В Україні 1918 року. Вісті комбатанта. Торонто; НьюЙорк, 1980. № 1. С. 74-82.

9. К. Три українські місії у Вашинґтоні. Ювілейний альманах 189-1944. Нью Джерсі, 1944. С. 291-293.

10. Карманський П. Наша політично-дипломатична акція в Південній Америці. Літопис Червоної Калини. Львів, 1939. Число 1. С 3-4.

11. Кобилянський Л. Українське посольство в Туреччині (1/XI 1918 22/IV 1919). Нова Україна. Прага, 1925. Червень-липень. С. 79- 91.

12. Онацький Є. По похилій площі. Записки журналіста i дипломата. Частина 1. Мюнхен: Дніпрова хвиля, 1964. 152 с. 
13. Прокопович В. Остання подорож. (31. XII. 1923-16. Х. 1924). Збірник памяти Симона Петлюри (1879-1926). Прага, 1930. С. 210-215.

14. Рудницький М. Париж 1919. Історичний календар-альманах "Червоної Калини" на 1939 р. Львів: Червона Калина, 1938. С. 119-128.

15. Русова С. Мемуари. Щоденник. Київ: Поліграфкнига, 2004. 544 с.

16. Смолій В. А., Верстюк В. Ф. Українська Центральна Рада: документи і матеріали: У 2 m. Нац. акад. наук України, Ін-т історії України. Т. 1. Київ: Наук. думка 1996. 589 С.

17. Стасів І. Дипломатичне представництво УНРеспубліки в Угорщині (1919 - 1922 роки). Визвольний шлях. Лондон, 1974. Кн. 6 (315). Річник XXVII. C. 663-673.

18. Трембіцький В. Документація українського державного самовизначення. Альманах Українського народного союзу на рік 1979. Джерсі Ситі; Нью-Йорк: Свобода, 1979. Річник 69-ий. С. 53-69.

19. Трембіцький В. Консуляти в Українській державі 1917-1920рр. і українська консульська служба. Вісник. Нью-Йорк, 1968. Рік XXII Ч. 2 (227). C. 21-22.

20. Трембіцький В. Останні дипломатичні представництва Української Народної Республіки (1920-1923). Календар Союзу українців-католиків Америки "Провидіння" на рік Божий 1982. Філадельфія, 1981. С. 253-296.

21. Трембіцький В. Український дипломатичний корпус 1917-1924 (До 70-х роковин державности 1919-1989). Альманах Українського Народного Союзу на рік 1989. Джерсі Сіті; Нью-Йорк: Свобода, 1989. Річник 79. С. 70-76.

22. Українець у Франції = L'ukrainien en France: українсько-французький порадник / Ф. Петренко (упоряд). Париж: Українська визвольна боротьба, 1934. $64 \mathrm{c}$.

23. Яковлів А. Вячеслав Костянтинович Прокопович (1881-1942). Записки Наукового товариства імени Шевченка. Париж; Нью-Йорк, 1954. T. CLXIII. C. 5-17.

\section{References}

1. Vasylkivskyi, L. (1970). Prychynky do istorii dyplomatii v 1917-21 rokakh (II) [Reasons to history of diplomacy in 1917-21]. Suchasnist [Modernity], 7- 8 (115-116), 140-152. Munich. [In Ukrainian].

2. Vasylkivskyi, L. (1970). Prychynky do istorii dyplomatii v 1917-21 rokakh (Diialnist Ukrainskoho posolstva u Shvaitsarii $v$ nasvitlenni d-ra medytsyny Yevmena Lukasevycha) [Reasons to history of diplomacy in 1917-21 (Activities of the Ukrainian Embassy in Switzerland in the coverage of medical doctor Yevman Lukasevich)]. Suchasnist [Modernity], 11(119), 75-92. Munich. [In Ukrainian].

3. Vesnianskyi, Z. (1968). Rozghrom ukrainskoho posolstva (za materialamy z "Storinky mynuloho" Prof. O. Lototskoho, ch. 4, 1939) [The defeat of the Ukrainian embassy (According to materials from "Pages of the past" prof. O. Lototskogo, part 4, 1939)]. Tryzub [Trident], 49, 19-24. Paris. [In Ukrainian].

4. Vynar, L. (1980). Yevhen Onatskyi - chesnist z natsiieiu. [Yevhen Onatskyi - honesty with the nation]. Ukrainskyi istoryk [Ukrainian historian], 14(65-68), 153-179. New York, Toronto, Munich. [In Ukrainian]. 
5. Halaichuk, B. (1955-1957). Dyplomatiia [Diplomacy]. Entsyklopediia Ukrainoznavstva: u 10 t. [Encyclopedia of Ukrainian Studies] Vol. 2, pp. 511-514. Paris, New York. [In Ukrainian].

6. (1920). Diialnist Ukrainskoi viiskovo-sanitarnoi misii u Vidni [The activities of the Ukrainian military sanitary mission in Vienna] Volia [Freedom], 166-171. Wien. [In Ukrainian].

7. Doroshenko, D. (1924). Moi spomyny pro nedavnie-mynule Chastyna chetverta. Pid Dyrektorieiu. Na chuzhyni (1919-1920) [My memoirs about the recent past. Pt. 4. Under Directory. In a foreign land (1919-1920)]. Lviv: Chervona Kalyna [In Ukrainian].

8. Zaleskyi, O. (1980). V Ukraini 1918 roku [ In Ukraine 1918]. Visti kombatanta [Kombatant's news], 1, 74-82. New York [In Ukrainian].

9. K. (1944) Try ukrainski misii u Vashyngtoni// Yuvileinyi almanakh 1894 1944 [ Jubilee almanac 1894-1944], 291-293. New Jersey. [In Ukrainian].

10. Karmanskyi, P. (1939) Nasha politychno-dyplomatychna aktsiia $v$ Pivdennii Amerytsi [Our political diplomatic action in South America] Litopys Chervonoi Kalyny [Chronicle of Red guilder rose] 1, 3-4. Lviv. [In Ukrainian].

11. Kobylianskyi, L. (1925) Ukrainske posolstvo v Turechchyni (1/XI 191822/IV 1919) [Ukrainian Embassy in Turkey(1/XI 1918-22/IV 1919)]. Nova Ukraina [New Ukraine], Pt. 2-3, 79-91. Prague. [In Ukrainian].

12. Onatskyi Ye. (1964.). Po pokhylii ploshchi. Zapysky zhurnalista $i$ dyplomata. [ On a sloping square. Notes by journalist and diplomat.] Pt. 1. Munich: Dniprova hvylya [In Ukrainian].

13. Prokopovych V. (1930) Ostannia podorozh (31.XII.1923-16. X.1924) [Last trip (31.XII.1923-16. X.1924)] Zbirnyk pamiaty Symona Petliury (18791926). [ Collection of Memoirs of Simon Petliura], 210-215. Prauge. [In Ukrainian].

14. Rudnytskyi M.(1938) Paryzh 1919.[Paris 1919]. Istorychnyi kalendaralmanakh "Chervonoi Kalyny" na 1939 r. [Historical Calendar of Almanac of Red guilder rose], 119-128. Lviv. [In Ukrainian].

15. Rusova S. (2004) Memuary. Shchodennyk.[Memoirs. Diary.]. Kyiv: Polihrafknyha [In Ukrainian].

16. Smolii V. A., Verstiuk V. F. (1996) Ukrainska Tsentralna Rada : dokumenty i materialy: $\cup 2 t$. [Ukrainian Central Rada: documents and materials: in 2 vols.]. Vol. 1, Kyiv: Nauk. dumka.[In Ukrainian].

17. Stasiv I. (1974) Dyplomatychne predstavnytstvo UNRespubliky $v$ Uhorshchyni (1919 - 1922 roky) [Diplomatic representation of the Republic of Hungary in Hungary (1919 - 1922)] Vyzvolnyi shliakh [Liberation path]. Book 6 (315), 663-673. London. [In Ukrainian].

18. Trembitskyi V. (1989) Ukrainskyi dyplomatychnyi korpus 1917-1924 (Do 70-kh rokovyn derzhavnosty 1919-1989) [Ukrainian diplomatic corps 1917-1924 (By the 70th anniversary of statehood 1919-1989)] Almanakh Ukrainskoho Narodnoho Soiuzu na rik 1989 [Almanac of the Ukrainian People's Union in the year of 1989]. Annual 79, 70-76. Jersey City; New York. [In Ukrainian].

19. Trembitskyi V. (1979) Dokumentatsiia ukrainskoho derzhavnoho samovyznachennia [Documentation of Ukrainian state self-determination] Almanakh Ukrainskoho narodnoho soiuzu na rik 1979 [Almanac of the Ukrainian People's Union in the year of 1979]. Annual 69, 53-69. Jersey City; New York. [In Ukrainian]. 
20. Trembitskyi V. (1968) Konsuliaty v Ukrainskii derzhavi 1917-1920 rr. i ukrainska konsulska sluzhba [Consulates in the Ukrainian state of 1917-1920. and Ukrainian consular service]. Visnyk [Herald]. Pt. 2 (227), 21-22. [In Ukrainian].

21. Trembitskyi V. (1981) Ostanni dyplomatychni predstavnytstva Ukrainskoi Narodnoi Respubliky (1920-1923) [Latest diplomatic representations of the Ukrainian People's Republic (1920-1923)]. Kalendar Soiuzu ukraintsiv-katolykiv Ameryky "Provydinnia" na rik Bozhyi 1982 [Calendar of the Union of Ukrainian Catholics in America "Providence" in the year of God 1982]. 253-296. Philadelphia [In Ukrainian].

22. Petrenko, F. (Comp.). (1934). Ukrainets u Frantsii = Lukrainien en France: ukrainsko-frantsuzkyi poradnyk [A Ukrainian in France= Lukrainien en France: Ukrainian-French counselor]. Paris: Ukrainska vyzvolna borotba. [In Ukrainian].

23. lakovliv, A. (1954) Viacheslav Kostiantynovych Prokopovych (18811942) [Viacheslav Prokopovych (1881-1942)] Zapysky Naukovoho tovarystva imeny Shevchenka [Notes of the Shevchenko Scientific Society] Vol. SLXIII, 5-17. Paris; New York [In Ukrainian].

\section{K. Petrychenko}

Researcher, Department of foreign Ukrainica, Vernadsky National Library of Ukraine

\section{Ukrainian foreign passport of Ukrainian revolution period (1917-1924) (based on the materials of the Department of Foreign Ukrainica at the Institute of Book Science of Vernadsky National Library of Ukraine)}

The article is devoted to the review of the literature of the department of foreign Ukrainica of the Book Science Institute of Vernadsky National Library of Ukraine on the study of the Ukrainian intemational passport throughout its period of its existence and use: from the moment of making a proposal for its introduction - on November 28, 1917, and until the time of the existence of diplomatic missions issuing Ukrainian passports - in 1924.

Its main focus is on memoirs of contemporary events: diplomats, statesmen, creative intelligentsia. The analysis of memoir literature suggests that it has important scientific significance, since it contains documentary evidence of the use of Ukrainian international passports for the departure of Ukrainian citizens, including Jews, to various European and American countries; highlights the existence of both diplomatic and ordinary Ukrainian international passports of various state entities of the period of the Ukrainian Revolution - the Ukrainian State, headed by hetman Pavlo Skoropadsky, the Ukrainian National Republic, and the Westem Ukrainian National Republic. In addition, the article deals with a considerable amount of details about the Ukrainian international passport in the literature of the Ukrainians abroad of the 1920's and 2000's. It focuses on highlighting the activities of Ukrainian diplomatic missions and consulates, their period of existence and the specifics of work, examples of Ukrainian passports and describes their appearance and meaning in the history of the development of Ukrainian statehood.

Key words: department of foreign Ukrainica of the Book Science Institute of Vernadsky National Library of Ukraine, memoirs, Ukrainian international passport, diplomacy, fund. 